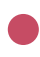

\title{
MAKE IT RAIN: THE SCIENCE BEHIND ALTERING THE WEATHER
}

WHENEVER HUMANKIND BELIEVES IT HAS CONTROL OVER THE NATURAL WORLD, THE WEATHER LIKES TO PROVE US WRONG. STORMS, FLOODS AND DROUGHTS ARE JUST SOME OF THE WEATHER PATTERNS THAT CAN COMPLICATE OR EVEN THREATEN HUMAN LIFE. WE HAVE INCREASINGLY SOPHISTICATED TECHNIQUES FOR WEATHER FORECASTING, BUT NOW SCIENTISTS ARE LOOKING EVEN FURTHER: TOWARDS DIRECTLY MODIFYING THE WEATHER ITSELF. DARREL BAUMGARDNER, OF THE NATIONAL AUTONOMOUS UNIVERSITY OF MEXICO AND DROPLET MEASUREMENT TECHNOLOGIES, RESEARCHES THE INTRIGUING TECHNIQUE OF CLOUD SEEDING

\section{TALK LIKE AN ATMOSPHERIC SCIENIIST}

CLIMATE - the general weather conditions over a long period.

\section{CLOUD CONDENSATION NUCLEI (CCN) - small particles} around which water vapour condenses and ultimately forms clouds.

\section{CLOUD SEEDING - intentionally adding CCN to the} atmosphere to change precipitation patterns.

DISDROMETER - a ground-based instrument to measure precipitation properties.
GEOENGINEERING - deliberate, large-scale intervention in the Earth's climate system, usually to mitigate climate change.

ICE NUCLEI (IN) - similar to CCN, particles in the atmosphere that ice crystals form around.

PRECIPITATION - water that falls from clouds to the ground, such as rain, hail, snow or sleet.

\section{SPECTROMETER - an instrument that measures spectral properties, such as the reflective properties of cloud particles.}

WEATHER - the state of the atmosphere of a particular area at a particular time.
Rain, or the lack of it, can cause problems. Too little rain can lead to droughts, which carries risks of crop failure and scarcity of drinking water. Too much rain can cause flooding and other forms of precipitation, such as hail, can cause physical damage to crops and property. Being able to influence when, where and how much rain falls could help prevent these negative effects.

Darrel Baumgardner has made a career of investigating clouds, not only how they form but also how humans can influence their formation. As well as working within academia, he is the founder and Chief Scientist at Droplet Measurement Technologies, which provides scientific instruments and expertise to researchers investigating aspects of cloud formation.

WHAT IS CLOUD SEEDING?

A key step in the water cycle is when water vapour in the atmosphere condenses into clouds, but this process can only occur with the presence of cloud condensation nuclei (CCN). These are essentially small particles of any number of substances, such as dust, soot or salt. To transition from a gas to a liquid, water molecules have to have something to cling onto, and CCN fulfil this function. Ice nuclei (IN) are the CCN equivalent for the formation of ice crystals in the atmosphere. 



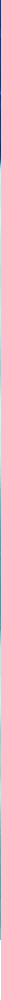

WHAT IS ATMOSPHERIC SCIENCE?

Atmospheric science studies the layers of gas that surround the planet, specifically their chemistry and their dynamics. This includes interactions within the atmosphere, and between the atmosphere and other entities, such as the ocean or human activity.

Our atmosphere is the relatively thin barrier that separates the Earth's surface from space. "Although the atmosphere makes up a small fraction of the Earth's volume, it is critical to life, not only for the oxygen we need but also for the hydrological cycle." The science that attempts to explain it is complex and detailed, but has come on in leaps and bounds in recent decades.

HOW HAS THE FIELD CHANGED OVER THE YEARS?

"We are now able to make faster and more accurate measurements with much smaller instruments," says Darrel. "We can also run computers hundreds of times more powerful than just a few decades ago." These huge advancements mean that understanding of atmospheric science is accelerating. "We know so much more about how clouds evolve than we did 50 years ago, but we still have a long way to go before we can truly 'control' weather," says Darrel.

\section{WHAT ARE THE REAL-WORLD APPLICATIONS OF ATMOSPHERIC SCIENCE?}

Weather forecasting, although it might seem a rather bland aspect of everyday life, has the potential to save countless lives. Forecasting tropical storms, tornados or hurricanes, for instance, can help people prepare and safeguard themselves and their livelihoods.

Atmospheric science also underpins much of what we know about climate change. "We know that climate change is real and is the greatest danger that the world faces today," says Darrel. Not only does atmospheric science provide us with much of the data about climate change - its predicted evolution and effects -, it also suggests ways we could protect ourselves against it.

Atmospheric science has a huge amount to teach us about the present and the future of our planet, and a career in it could have farreaching positive impacts for society.

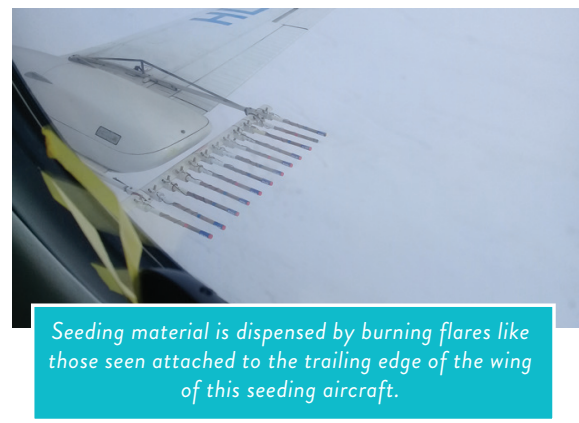

\section{HOW TO BECOME AN ATMOSPHERIC SCIENHIST}

- According to NASA, a career in atmospheric science could begin with an undergraduate degree in meteorology, physics, chemistry, geography, mathematics, engineering or computer science.

- The Royal Meteorological Society has a list of UK universities that offer qualifications related to atmospheric science:

https://www.rmets.org/courses

- According to College Factual, the top three universities in the USA for studying atmospheric science and meteorology are: Texas A\&M University - College Station; University of California - Los Angeles; and University of Oklahoma Norman Campus

- Darrel highlights the University of Washington, the University of Wyoming, the Massachusetts Institute of Technology (MIT), Colorado

State University and North Carolina State University as establishments to consider. 
$\circ$

\section{HOW DID DARREL BAUMGARDNER BECOME AN ATMOSPHERIC SCIENTISTR}

WHAT WERE YOUR INTERESTS AS A CHILD?

I was always curious as a child. I had my own chemistry set, Meccano, and lots of other educational toys that were available at that time. I enjoyed exploding things, taking things apart and putting them back together again. For a time, I was interested in becoming a writer, but decided to become a physicist at high school.

\section{DID YOUR TEACHERS INFLUENCE} YOUR DECISIONS?

I was lucky to have several inspirational teachers. My math teachers and my senior year physics teacher energised me with their enthusiasm for their subjects. A skilled teacher is driven by their curiosity and is someone who students want to emulate.
WHAT ARE YOU MOST PROUD OF FROM YOUR CAREER?

I have been a university professor for fourteen years and a research scientist for forty. I also have a patented design: the Backscatter Cloudprobe with Polarisation Detection. I have won an award for being the most cited Latin American scientist, with over 200 high-impact publications. I also founded my own tech company that does atmospheric research, which is still going strong after thirty years!

HOW DO YOUR ROLES IN ACADEMIA AND INDUSTRY COMPLEMENT EACH OTHER?

Many of my company's clients are academics, and I interact with them and their students. I often visit universities and

give classes in cloud and aerosol physics, as well as teaching measurement and data analysis techniques.

WHAT'S NEXT?

I have too many goals to name! I hope to improve techniques for measuring cloud ice crystal properties, and to develop a better method for identifying pollen particles in real time.

\section{DARRELS TOP TIPS FOR STUDENIIS}

01 - Follow your instincts, and don't doubt yourself. Once you have made a decision, don't look backwards or regret your choice.

02 - Attributes such as curiosity, problem solving, creativity and exploring my own wild ideas have hugely helped my scientific career.

Darrel recommends taking:

MATHS

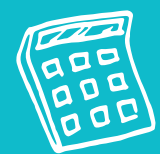

CHEMISTRY
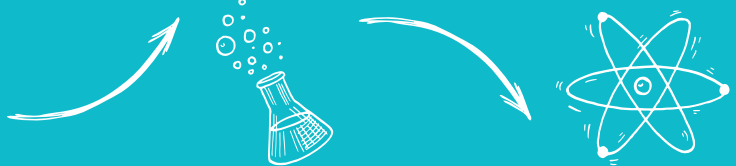

$\mathbf{0 3}$ - Let your creativity grow and don't limit yourself. Being able to write well is essential, so read widely: history, literature, fiction, non-fiction. Music can also provide a great creative outlet.
ENVIRONMENTAL SCIENCES

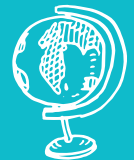

Other subjects such as geography and computer science could also be very useful.
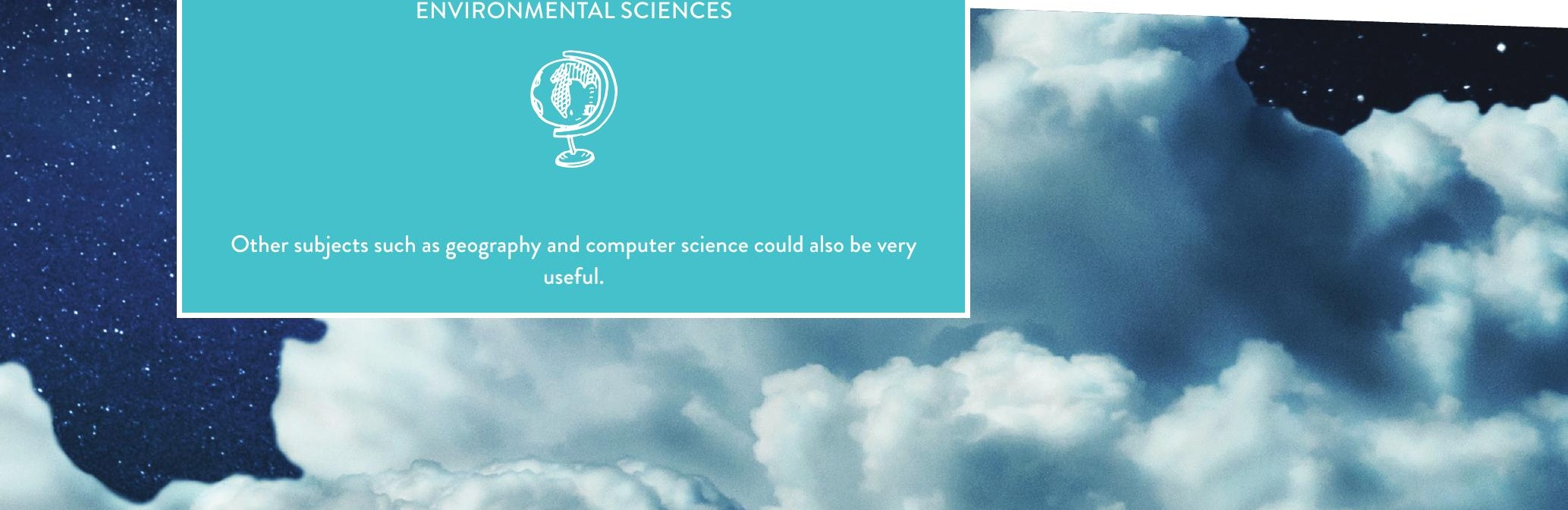